UDK $630 * 228(234.422$ Bjelašnica)(253)

\title{
STRUCTURAL CHARACTERISTICS, DYNAMICS AND TEXTURE DEVELOPMENT OF VIRGIN FOREST RAVNA VALA ON BJELAŠNICA
}

Strukturne karakteristike, dinamika i teksturni razvoj prašume Ravna vala na Bjelašnici Ćemal Višnjić ${ }^{1}$, Besim Balić ${ }^{1}$, Sead Vojniković ${ }^{1}$, Faruk Mekić ${ }^{1}$, Amir Uzunović ${ }^{2}$

\begin{abstract}
This work researches structural composition, texture and diversity of development phases of virgin forest „Ravna vala“ on Bjelašnica. Virgin forest „Ravna vala“ is located in central part of Bosnia and Herzegovina, about $20 \mathrm{~km}$ south west from Sarajevo on mountain Bjelašnica, on altitude of 1280 to $1450 \mathrm{~m}$. First time it was described in 1978. Within it we have positioned permanent plot of the square shape in size of 1 ha. Research was conducted on permanent plot in three time series: in years 1978, 1988 and 2008, and on 46 temporary systematically positioned circular plots in diameter of 12.6 meters, where each represents as per 1 ha of virgin forest area. In virgin forest we have registered 689 trees per hectare and wood supply mass of 701 $\mathrm{m}^{3} / \mathrm{ha}$. Through analysis of dynamics of growth of specific species trees, it is visible that beech suppresses fir, i.e. there is a shift in main species in virgin forest, therefore, in the last 30 years number of beech trees has tripled in the lower diameter classes. Virgin forest has mostly present optimum phase and evenness phase, and rejuvenation phase. Texture diversity is expressed through Shannon index in value of 1.69 , and evenness index has the value of 0.86 .
\end{abstract}

Key words: Beech; fir; virgin forest; time series, development phases

\section{INTRODUCTION - Uvod}

Virgin forests are very important reference areas for research of natural structures and processes that are ongoing without anthropogenic influence. By comparison of virgin with management forests, one can have an insight in man influences and what kind of activities can be conducted in the future (DROESSLER 2006). In most European countries silviculture goals are oriented toward natural multifunctional forest management. In the process there is often lack of reference values from anthropogenically intact forests - virgin forests, or they are presented theoretically (MEYER et al. 2001). Contrary to that, Balkan Peninsula has remaining virgin forests where many researches have been conducted (LEIBUNDGUT 1993, KORPEL 1995, TABAKU 1999, VRŠKA et al. 2001, MEYER et al. 2003, ANIĆ et al.

\footnotetext{
${ }^{1}$ Faculty of Forestry, University of Sarajevo

${ }^{2}$ Forest administration of ZD Kanton
} 
2006, DUBRAVEC et al. 2006, 2007, VIŠNJIĆ et al. 2009, DIACI et al. 2011, VIŠNJIĆ et al. 2013).

Inside forests of beech and fir with spruce in Bosnia and Herzegovina there are sections intact by man - virgin forests. Most of them have been separated and described many decades ago, such as: Perućica, Ravna Vala, Bobija, Plješevica (PINTARIĆ 1978, LEINBUNDGUT 1986, PINTARIĆ 1998, BEUS and VOJNIKOVIĆ 2002, SEBASTIA et al 2005, VIŠNJIĆ et al. 2009, 2013), where their structural and vegetation characteristics have been researched.

In this paper we have researched structure, dynamics, texture composition within virgin forest of beech and fir with spruce "Ravna vala" on Bjelašnica.

\section{MATERIAL AND METHODS - Materijal i metode}

\section{Object of research}

Researches are conducted in virgin forest of beech and fir with spruce "Ravna vala" on Bjelašnica. Virgin forest "Ravna vala" is located in central section of Bosnia and Herzegovina, about $20 \mathrm{~km}$ south west from Sarajevo on mountain Bjelašnica, on altitude of 1280 to $1450 \mathrm{~m}$ Virgin forest is exposed towards north east. It has an area of 45.04 hectares (Figure 1).

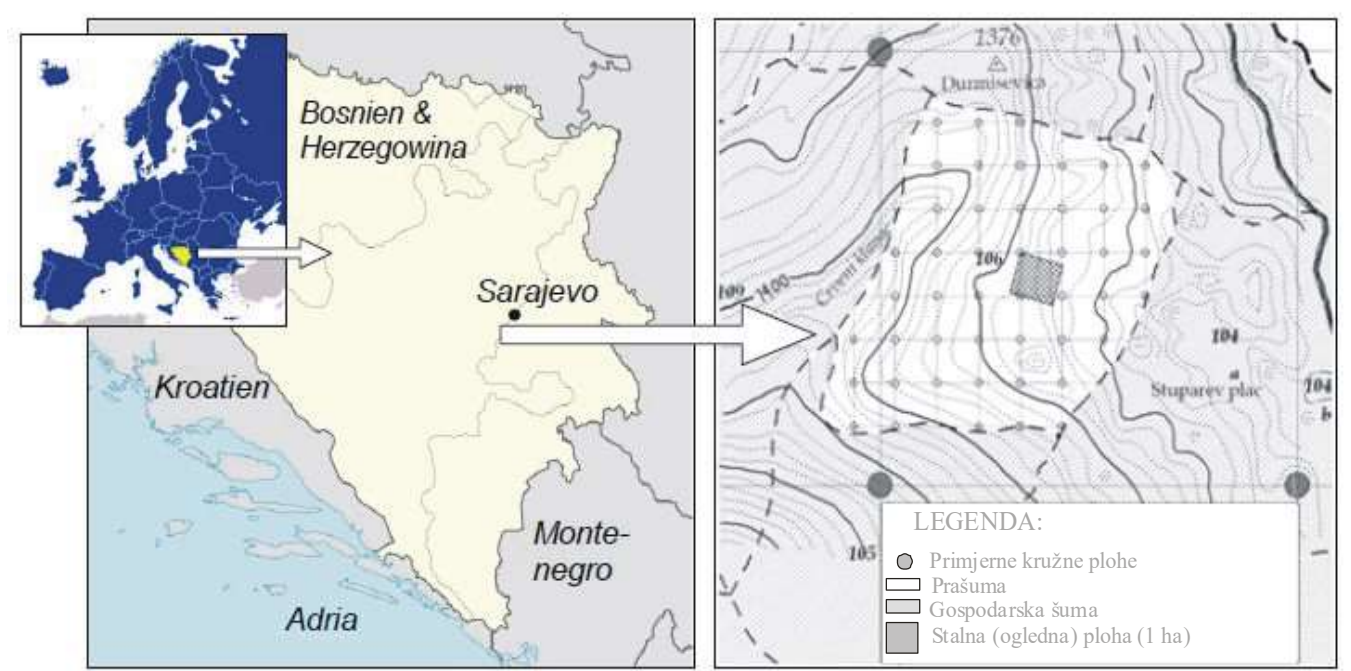

Figure 1. Location of virgin forest reserve "Ravna vala"

Slika 1. Lokacija prašumskog rezervata "Ravna vala"

Parent substrate is made of limestone and dolomite as well as moraine debris on which, in mosaic manner, on smaller surfaces, soils of different depths have grown: rendzina, kalkomelansol, and calcaric cambisol (ĆIRIĆ, 1966). Climate is continental with strong mountain influence (LUČIĆ, 1966). Average annual temperature is $6^{\circ} \mathrm{C}$, and annual precipitation sum is $1600 \mathrm{~mm}$. 
Research area is dominated by communities of beech and fir (Abieti-Fagetum TREG. 1957), in which spruce can also appear. Individually or in smaller groups in depressions on deeper soils, valuable broadleaved species appear; sycamore maple (Acer pseudoplatanus) and wych elm (Ulmus glabra).

\section{Work methods}

Virgin forest "Ravna vala" was described in 1978 when it has been separated and within it placed permanent plot square in shape in size of 1 ha. On permanent plot, in many occasions, measurement of all trees of diameter above $10 \mathrm{~cm}$, measured on height of $1.3 \mathrm{~m}\left(\mathrm{~d}_{1,3} \mathrm{~m}>10 \mathrm{~cm}\right)$ was conducted, in years 1978, 1988 and 2008. These data were used for analysis of beech and fir tree growth dynamics within virgin forest. On whole area of virgin forest (45.04 ha) recordings of taxation elements on sample plots, in diameter of $12.5 \mathrm{~m}$, were done. In total, 46 sample plots with systematic dispersal were placed, in a way that each represented 1 ha of virgin forest area (Figure 1). Complete measurement of all trees of more than $5 \mathrm{~cm}$ in diameter, on $1.3 \mathrm{~m}$ of height, was conducted on all plots.

As indicator to texture diversity development phases were used, that were determined by MEYER method (1999). To quantify development phases within virgin forest, three experimental plots, square in shape with sides in length of 75 meters, were placed. Distribution of these plots within virgin forest was random. Each plot was divided into 36 equal smaller plots, square in shape with sides in length of 12.5 meters. Affiliation of each small plot to virgin forest development phase, by using MEYER method (1999), was conducted (Table 1). Development phases are presented graphically in topographic method. Average texture diversity of virgin forest was calculated based on presence of development phases and their participation in percentage on research plots.

Table 1. Virgin forest development phases by MEYER 1999.

Tabela 1. Razvojne faze prašume po MEYER 1999.

\begin{tabular}{|l|l|}
\hline \multicolumn{1}{|c|}{$\begin{array}{c}\text { Virgin forest } \\
\text { development phases }\end{array}$} & \multicolumn{1}{c|}{ Description } \\
\hline Clearing-gap phase & $\begin{array}{l}\text { Canopy density is smaller than } 25 \% \text {, and rejuvenation i.e. coverage of natural } \\
\text { young growth on area is less than } 50 \% .\end{array}$ \\
\hline Rejuvenation phase & $\begin{array}{l}\text { Young growth, that covers more than } 50 \% \text { of area, is growing in broken } \\
\text { canopy density of tree tops, or inside the stand that is in decomposition phase. }\end{array}$ \\
\hline Optimum phase & $\begin{array}{l}\text { Starts when trees reach diameter of } 7 \mathrm{~cm} \text { on } 1.3 \mathrm{~m} \text { of height. It is characterized } \\
\text { by good increment, i.e. net production of wood mass and reduction of tree } \\
\text { number due to strong competition. }\end{array}$ \\
\hline Evenness phase & $\begin{array}{l}\text { Long-term constant in net growth (production and decomposition) in high } \\
\text { cycle of growth, and dying-out. }\end{array}$ \\
\hline Regeneration phase & $\begin{array}{l}\text { Net production of wood mass is increasing in significant portion through } \\
\text { increment of remaining trees in the stand. }\end{array}$ \\
\hline Terminal phase & $\begin{array}{l}\text { Long-term constant in net growth (production and decomposition) due to } \\
\text { small or missing cycle of production and decomposition. }\end{array}$ \\
\hline Decomposition phase & $\begin{array}{l}\text { Strong degradation of large tree net mass happens, which is a lot larger than } \\
\text { the increment and it cannot be annulled by large tree regeneration processes. }\end{array}$ \\
\hline
\end{tabular}




\section{RESULTS - Rezultati}

\section{Structural characteristics}

\section{Number of trees}

In virgin forest we registered average of 689 trees per one hectare. Distribution of number of trees per diameter classes has a form of declining curve that at the beginning suddenly drops and then is asymptotically getting close to zero (Graphic 1). Out of tree species, beech dominates with participation of over 77\% (533 trees), out of which the largest number is in the lowest diameter class $(10 \mathrm{~cm}), 419$ trees. Unlike beech, other species do not have expressed declining sequence with diameter increase.

Besides beech, out of main tree species, there is 127 trees of fir, i.e. $18.4 \%$, while there is the least of spruce, 15 trees $(2.18 \%)$.

Out of other species present in virgin forest we have to mention maple (Acer) and mountain-ash (Sorbus aucuparia). Maple is registered in all diameter classes up to $70 \mathrm{~cm}$ and participates with $1.89 \%$ (13 trees). Mountain-ash is recorded only in the lowest diameter class of $10 \mathrm{~cm}$, and its participation is negligible (below $1 \%$ ).

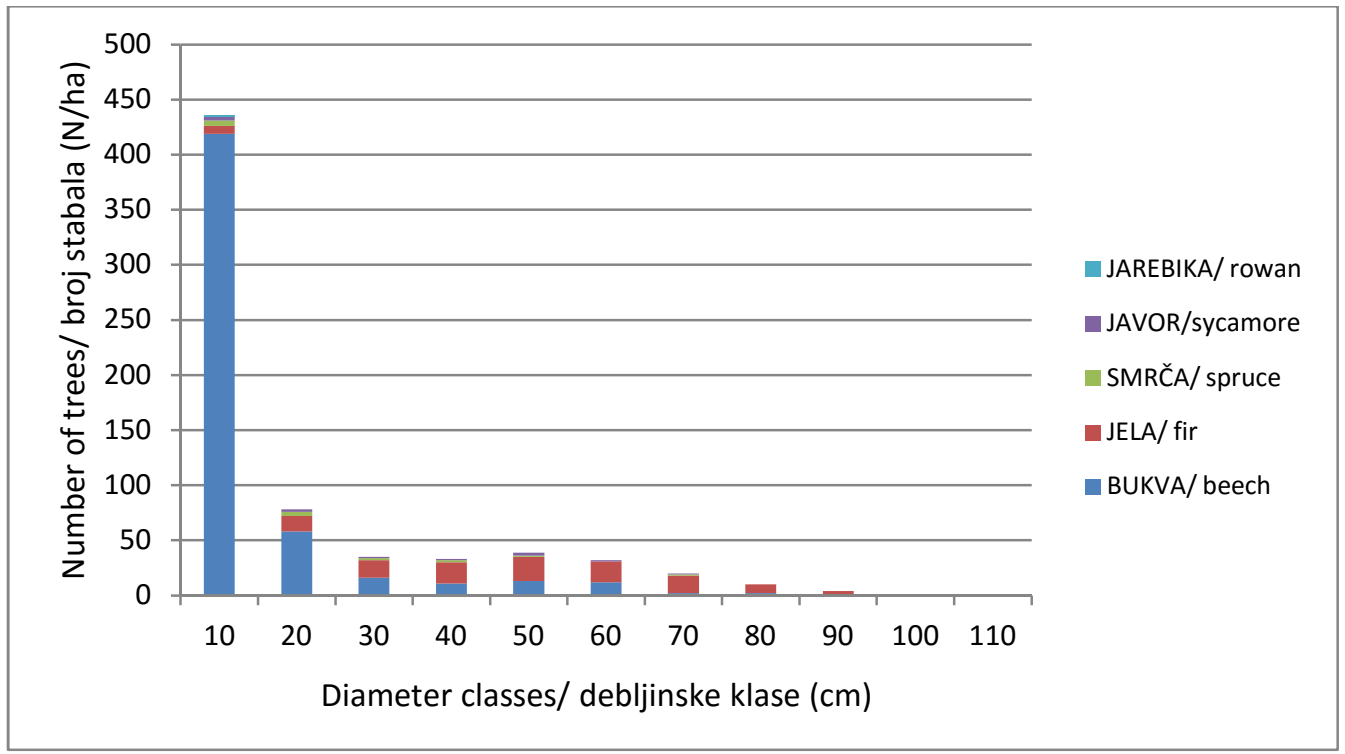

Graphic 1. Distribution of trees per diameter classes of all tree species in virgin forest "Ravna vala"

Grafik 1. Raspodjela stabala po debljinskim klasama svih vrsta drveća u prašumi "Ravna vala" 


\section{Stock}

Total stock in virgin forest is $701 \mathrm{~m}^{3} /$ ha, where largest portion has the fir with stock of $463.7 \mathrm{~m}^{3} /$ ha, i.e. $66.2 \%$, than beech with $197.7 \mathrm{~m}^{3} /$ ha or $28.2 \%$, maple with $25.1 \mathrm{~m}^{3} /$ ha or $3.6 \%$, spruce with $14.5 \mathrm{~m}^{3} /$ ha or $2.1 \%$, and mountain-ash below $1 \%$ of total stock. Although beech dominates in tree numbers, fir has the largest portion in the stock, which is concentrated in larger diameter classes $(>50 \mathrm{~cm})$, in which larger number of fir trees are present (Graphic 2).

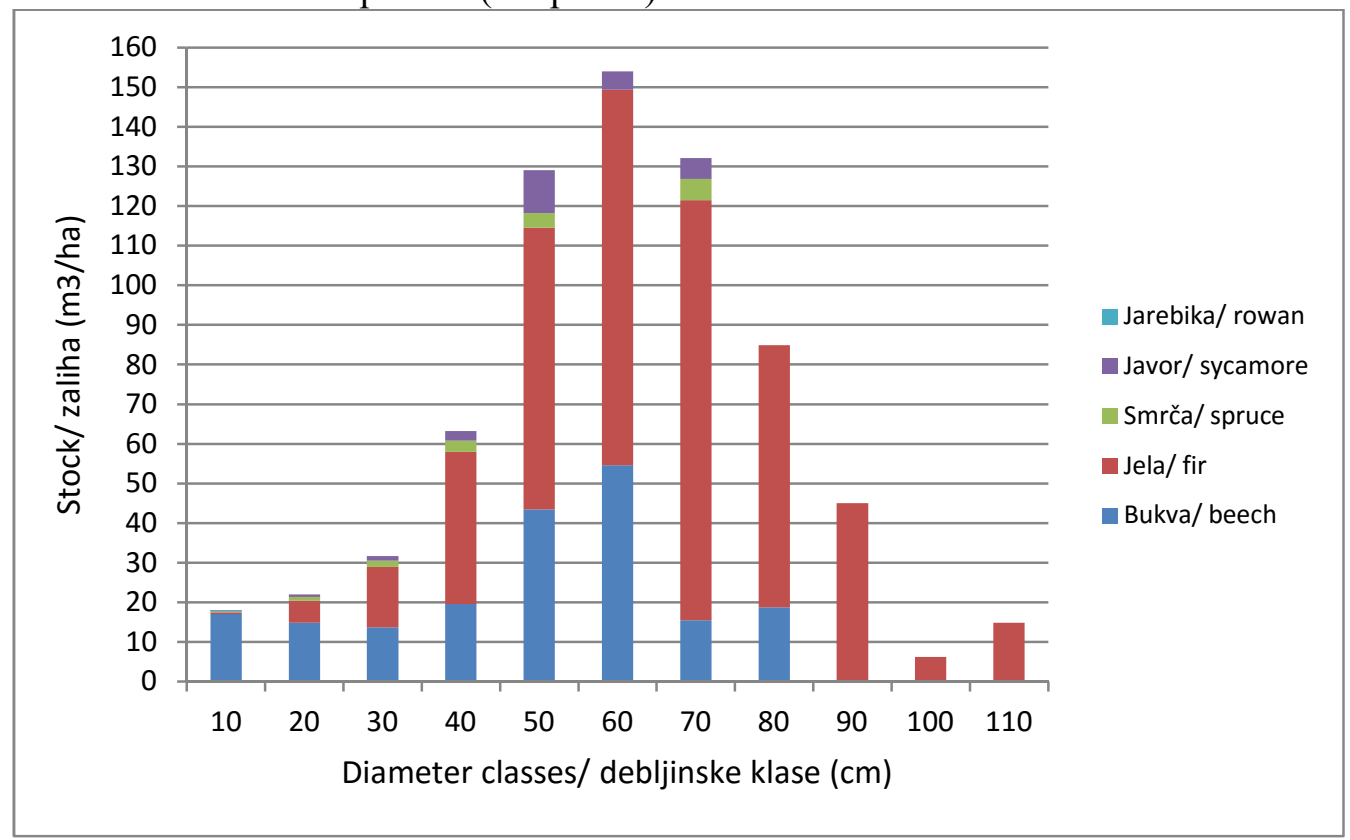

Graphic 2. Distribution of stock per diameter classes and tree species in virgin forest "Ravna vala"

Grafik 2. Raspodjela zalihe po debljinskim klasama za sve vrste u prašumi "Ravna vala

\section{Development phases and texture diversity}

Table 2 presents participation, in percentage, of individual development phases on examined plots within virgin forest. Participation of individual development phases on examined plots varies, but domination of the same development phases on all three plots is noticeable. Therefore one can see that rejuvenation phase participates with $21.3 \%$, evenness phase with $24.9 \%$ and optimum phase with $28.7 \%$, and these value vary a little on all three plots. Clearing/gap phase participates with $12 \%$ while percentage participation of remaining development phases is significantly smaller. Regeneration phase participates on $6.4 \%$ of the area, terminal phase on approximately $3.6 \%$, while decomposition phase participates on only $2.7 \%$ of virgin forest area. 
Table 2. Percentage share of development phases in virgin forest "Ravna Vala" Tabela 2. Procentualni udio razvojnih faza u prašumi "Ravna vala"

\begin{tabular}{|l|c|c|c|c|}
\hline Development phases/ razvojne faze & $\begin{array}{c}\text { Plot 1 } \\
(\%)\end{array}$ & $\begin{array}{c}\text { Plot 2 } \\
(\%)\end{array}$ & $\begin{array}{c}\text { Plot 3 } \\
(\%)\end{array}$ & $\begin{array}{c}\text { Mean (\%) } \\
\text { sredina }\end{array}$ \\
\hline Clearing-gap phase/ faza progale & 0 & 16.6 & 19.4 & 12.0 \\
\hline Rejuvenation phase/ faza podmlađivanja & 22.2 & 19.4 & 22.2 & 21.3 \\
\hline Optimum phase/ optimalna faza & 33.3 & 25 & 27.7 & 28.7 \\
\hline Evenness phase/ faza izjednačavanja & 27.7 & 27.7 & 19.4 & 24.9 \\
\hline Regeneration phase/ faza regeneracije & 8.3 & 5.5 & 5.5 & 6.4 \\
\hline Terminal phase/ terminalna faza & 2.7 & 2.7 & 5.5 & 3.6 \\
\hline Decomposition phase/ faza raspadanja & 5.5 & 2.7 & 0 & 2.7 \\
\hline
\end{tabular}

In Figure 2 we can see that all development phases appear in virgin forest. Larger groups build rejuvenation phase, optimum phase and evenness phase. These groups are mutually connected into groups and make more-less large groups, while individually, on whole area on examined plots, regeneration phase, terminal phase and decomposition phase appear (Figure 2).

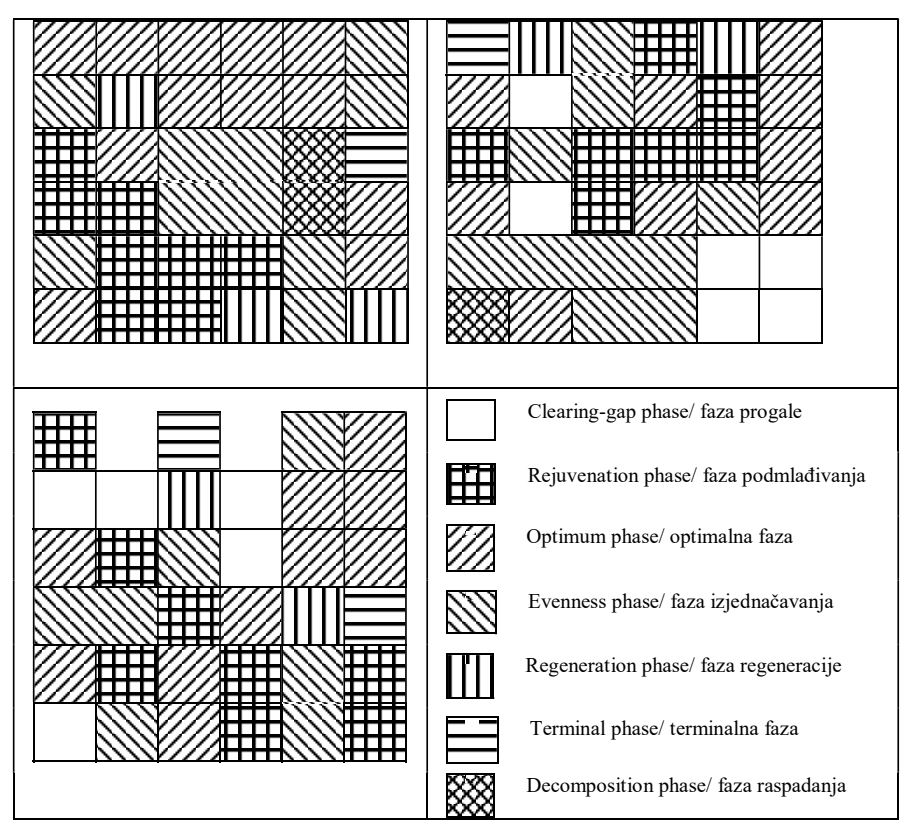

Figure 2. Development phases of the virgin forest on small areas with $12.5 \mathrm{~m}$ edge length Slika 2. Prostorni raspored razvojnih faza unutar prašume, na plohama dužine stranice 12,5 $m$.

Presence of all 7 development phases in virgin forest and approximately the same participation of three dominant development phases on examined plots, as well 
as uniform participation of other phases, although with smaller participation, point out the high texture diversity (1.69) which is depicted through relatively high evenness index with mean of 0.86 . (Table 3 ).

Table 3. Texture diversity of virgin forest calculated on the basis of development phases Tabela 3. Teksturni diverzitet prašume izračunat na osnovu broja i zastupljenosti razvojnih faza

\begin{tabular}{lcc}
\hline \multirow{2}{*}{ Plots/ plohe } & \multicolumn{2}{c}{ Index } \\
\cline { 2 - 3 } & Shannon & Evenness \\
\hline Plot 1/ ploha 1 & 1,52 & 0,85 \\
Plot 2/ ploha 2 & 1,68 & 0,86 \\
Plot 3/ ploha 3 & 1,65 & 0,92 \\
\hline Mean/ sredina & 1,69 & 0,86 \\
\hline
\end{tabular}

\section{Dynamics}

Transition of number of trees of certain tree species in function of time in the virgin forest can be seen through comparison of the share/participation of individual tree species in three surveys in years 1978, 1988 and 2008. Total number of trees of all tree species with diameter larger than $10 \mathrm{~cm}$ on $1.3 \mathrm{~m}$ height is shown in Table 4 . From the table is visible that in year 1978 permanent plot within virgin forest had 346 trees and that their number is increasing. In 1988 there were 387, while number of trees in 2008 was 478 . In the process it is visible that ratio of number of trees of beech and fir in mentioned time interval (1978-2008) has completely changed. In 1978 fir was dominant species with 210 trees, while beech had a share of 102 trees, while in the measurement in 2008 on the plot there was 224 trees of beech and 172 trees of fir. Similarly, but in smaller volume, we have had a behavior of spruce and maple. While number of trees of spruce gradually decreased, number of trees of maple has increased.

Table 4. Development of the total number of trees of individual species on permanent plot (1ha) in the virgin forest (1978-2008)

Tabela 4. Izmjena broja stabala glavnih vrsta drveća između 1978-2008. godine na trajnoj plohi u prašumi

\begin{tabular}{lrrr}
\hline Species/ vrste & $\mathbf{1 9 7 8}$ & $\mathbf{1 9 8 8}$ & $\mathbf{2 0 0 8}$ \\
\hline Beech/ bukva & 102 & 144 & 224 \\
Fir/ jela & 210 & 209 & 172 \\
Spruce/ smrča & 20 & 19 & 14 \\
Sycamore/ javor & 14 & 15 & 23 \\
\hline Total/ ukupno & 346 & 387 & 478 \\
\hline
\end{tabular}


Increase in number of trees of beech is particularly visible in diameter class of $20 \mathrm{~cm}$. (Graphic 3). Number of trees in that diameter class in period 1978-2008 nearly tripled. Also, in diameter class of 21-40 cm, there was increase in number of trees of beech but not in such large ratio. Decrease in number of trees of fir is mostly noticeable in lower diameter classes of fewer than $40 \mathrm{~cm}$. In larger diameter classes $(41-60 \mathrm{~cm}$ and $>60 \mathrm{~cm})$ number of trees of beech remained almost the same, but in fir it has mildly increased, particularly in diameter class $>60 \mathrm{~cm}$ and in period 19781988. Such trend clearly point out the shift of tree species within virgin forest, i.e. it is visible that fir is being suppressed by the beech.
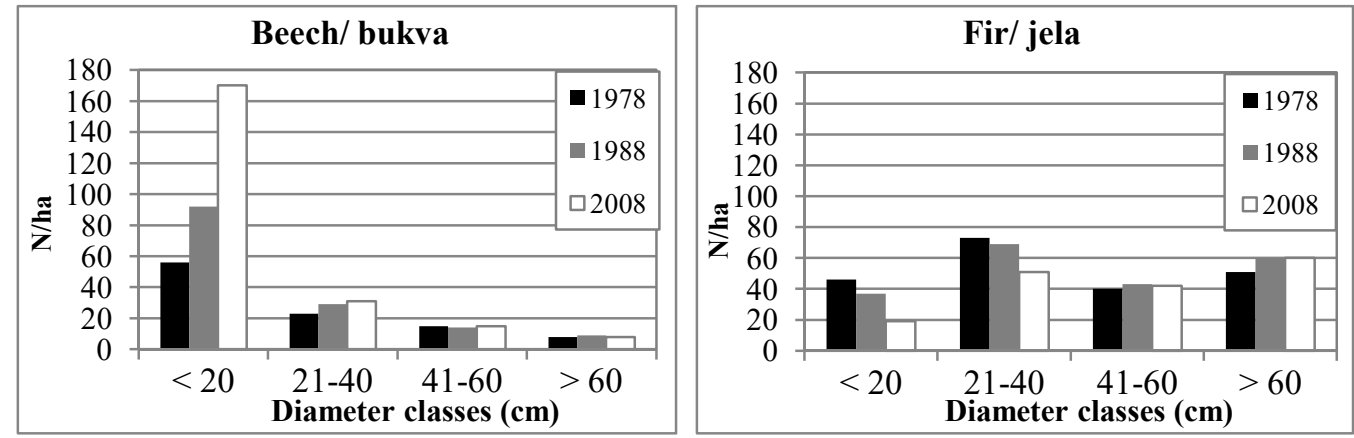

Graphic 3. Dynamics of beech (Fagus sylvatica) and fir (Abies alba) diameter structure, 1978 to 2008

Grafik 3. Dinamika debljinske strukture bukve (Fagus sylvatica) i jele (Abies alba) od 1978 do 2008

\section{DISCUSSION - Diskusija}

\section{Structure (diameter and stock)}

In virgin forest "Ravna vala" we have determined average of 638 trees per hectare, whereby beech dominates with $77 \%$ while fir participates in only $18 \%$ of the total number of trees. In research in virgin forest "Plješevica" in north-western Bosnia the determined number of trees per hectare was 652 (VIŠNJIĆ et al. 2009). There also dominates beech with participation of $64 \%$. Almost the double smaller number of trees per hectare where recorded by ANIĆ et al. (2008) in beech-fir virgin forest "Ćorkova uvala" in Croatia (440 st/ha) with participation of beech of $49 \%$ and fir of $45 \%$.

All these researches talk about recent domination of beech in Dinaric virgin forests especially in lower diameter classes, while fir is dominant if higher diameter classes. This clearly says that beech takes over domination and gradually suppresses fir (DUBRAVEC et al. 2006, 2007, DIACI, et al. 2008, ANIĆ, 2008, VIŠNJIĆ 2009).

In respect of stock, there is in average of $701 \mathrm{~m}^{3} /$ ha of live wood mass in virgin forest "Ravna vala". If these results are compared with researches in virgin forests of beech and fir in the region; north Bosnia $772 \mathrm{~m}^{3} /$ ha (VIŠNJIĆ et al. 2009), 
Croatia $671.23 \mathrm{~m}^{3} /$ ha (ANIĆ and MIKAC. 2008) and Slovenia approximately 800 $\mathrm{m}^{3} / \mathrm{ha}$ (DIACI et al. 2008), we cannot find larger differences. Unlike beech domination in diameter class per number of trees, here in total stock dominates fir which is similar in the other researches. Domination of fir in the stock is explained in larger participation of fir per number of trees in diameter classes above $40 \mathrm{~cm}$.

\section{Texture diversity}

Analysis of texture diversity spots the transition of individual development phases of virgin forest on small area, whereby the most representation is of optimum phase $(28.7 \%)$, evenness phase $(24.9 \%)$ and rejuvenation phase $22 \%$. In researches of development phases of Albanian virgin forests conducted by TABAKU (1999) terminal phase dominated with $50 \%$. Researches conducted by LEINBUNDGUT (1993) in beech-fir virgin forest Perućica, also show domination of terminal phase and initial decomposition phase with the share of $40 \%$. Larger share of terminal phase of $60 \%$ were found by ANIĆ AND MIKAC (2008) in their researches. Dominance of terminal phase is typical characteristic of Dinaric beech-fir virgin forests. Expressed relief of Dinaric Mountains gives protection to these forests from the wind. Because of that there is large number of old living and dying standing trees that characterize terminal phase (ANIĆ AND MIKAC 2008). However, in virgin forest "Ravna vala" already appeared the transition of old trees and rejuvenation is abundant on whole area which is visible from the share of rejuvenation phase which is in the third place with $22 \%$ of participation. Larger bare areas were not spotted, but there is presence of dying of old trees on whole area which opens up possibility for growth of young trees especially of beech.

Average texture diversity of virgin forest "Ravna vala" shows Shannon index of 1.69 while evenness index is 0.86 . Tabak (1999) in researches on texture diversity of Albanian virgin forests gained similar values. Shannon index had a value between 1.5-1.7 while evenness index varied between 0.7 and 0.8 .

\section{Dynamics}

Analysis of dynamics of diameter structure development per number of trees of specific tree species showed that in 30-year period number of beech trees in diameter classes up to $20 \mathrm{~cm}$ nearly tripled, while number of fir trees in the same diameter classes was halved. Researches of DIACl et al. (2008) inside Slovenian virgin forests showed that share of fir in virgin forests is decreasing, and share of beech is increasing, while in largest diameter classes fir still dominates. Similarly in researches of LEIBUNDGUT (1993), KORPEL (1995), BONČINA et al. (2003), SEBASTIA et al. (2005) and DUBRAVEC et al. (2007) show expressed domination of beech in young trees and lower diameter classes. This points-out the fact that we have ongoing transition of tree species, where in future beech will take over a role of dominant species inside Dinaric virgin forests of beech and fir with spruce. Since impact of man in virgin forests is excluded, and emission of harmful gases does not have expressed 
direct impact, all says that transition of main tree species is basically reaction to actual climate changes.

\section{CONCLUSIONS - Zaključci}

Number of trees per hectare and wood mass stock gained with these researches match similar researches in the region, which points to conclusion that Dinaric virgin forests of beech and fir are stable forest communities. In them there is no stronger disturbance of the status, and expressed Dinaric relief provides them with protection from storm winds. Trees die individually on whole area and their position is abundantly regenerated by young growth of the same or other tree species which fill out the gaps. That way, number of trees inside virgin forests significantly does not change as well as virgin forest stock. In virgin forest "Ravna vala" currently is ongoing transition process of main tree species. Beech in lower diameter classes replaces fir and slowly suppresses it. This trend shall continue in the future when beech will take a main role also in larger diameter classes. Transition of main species is under influence of natural factors, and largest influence represents climate changes. That virgin forest "Ravna vala" is stable forest community is shown by its texture and texture diversity. Virgin forest has all 7 development phases. Development phases are not grouped, but appear on smaller areas in whole virgin forest which additionally increases stability of virgin forest and enables more uniform transition from one phase into another without expressed turbulences on larger area of the virgin forest. The most present are optimum development phase, rejuvenation phase and evenness phase each with over $20 \%$ of share in the area of virgin forest. Texture diversity as indicator of structural diversity has value of 1.69 which concurs with researches in the region, while evenness index is very high and has value of 0.86 . These indexes confirm mentioned statements that virgin forest "Ravna vala", even beside much expressed dynamic changes, is very stable and divergent forest ecosystem.

\section{REFERENCES - Literatura}

ANIĆ, I., MIKAC, S., ORŠANIĆ, M., DRVODELIĆ, D. (2006): Structural relations between virgin and management beech-fir stands (Omphalodo-Fagetum Marinček et al. 1992) in forests of the Croatians Dinaric Karst. Periodicum Biologorum, 108 (6), 663-669.

ANIĆ, I., MIKAC, S. (2008): Struktura, tekstura i pomlađivanje dinarske bukovo jelove paršume Čorkova Uvala. Šumarski list br. 11-12, 505-515.

ALBRECHT, L. (1991): Die Bedeutung des toten Holzes im Wald. Forstwissenschaftliches Centralblatt 110, 106-113.

AMMER, U. (1991): Konsequenzen aus den Ergebnissen der Totholzforschung fuer die forstliche Praxis. Forstwissenschaftliches Centralblatt, 110, 149-157. 
BEUS, V., VOJNIKOVIĆ, S. (2002): Floristical characteristics of the virgin forest of beech and fir in Ravna Vala on mountain Bjelašnica. Razp. IV. razreda SAZU. XLIII, Ljubljana, 63-78.

BEUS, V., VOJNIKOVIĆ, S. (2006): Floristički diverzitet prašume i gospodarske šume u Ravnoj vali na Bjelašnici; Zbornik radova: Gazdovanje šumskim ekosistemima nacionalnih parkova i drugih zaštićenih područja, Jahorina - Tjentište, str. 55-66.

BONČINA, A., GAŠPERŠIC, F., And DIACI, J. (2003): Long-term changes in tree species composition in the Dinaric mountain forests of Slovenia. The Forestry Chronicle 79 (2), 227-232.

DIACI, J., ROŽENBERGAR, D., MIKAC, S., ANIĆ, I., HARTMAN, T., BONČINA, A. (2008): Long-term changes in tree species composition in old- growth dinaric beechfir forest. Glasnik za šumarske pokuse, Vol. 42, 13-27, Zagreb.

DIACI, J., ROŽENBERGAR, D., ANIĆ, I., MIKAC, S., SANIGA, S., KUCBEL, M., VIŠNJIC, Ć., and BALLIAN, D. (2011): Structural dynamics and synchronous silver fir decline in mixed old-growth mountain forests in astern and Southeastern Europe. Forestry, 84. 479.491.

DZWONKO, Z., LOSTER, S., DUBIEL, E. AND DRENKOVSKI, R. (1999): Syntaxonomic analysis of beechwoods in Macedonia (former Republic of Yugoslavia). Phytocoenologia 29, $153-175$.

DRÖßLER, L.(2006): Struktur und Dynamik von zwei Buchenurwäldern in der Slowakei. Dissertation, Göttingen.

DUBRAVEC, T., ČAVLOVIĆ, J., ROTH, V., VRBEK, B., NOVOTNY, V., DEKANIĆ, S. (2006): The structure and possibility of natural regeneration in managed and nonmanaged beech and fir forests in Croatia. Periodicum Biologorum, Vol. 108, No 6.

DUBRAVEC, T., DEKANIĆ, S. (2007): Utjecaj strukture sastojine na dinamiku razvoja mladoga naraštaja i potrajnost šume bukve i jele u nacionalnom parku Risnjak. Šumarski list, Zagreb, br. 11-12.

KORPEL, Š . (1995): Die Urwälder der Westkarpaten. Stuttgart, Jena, New York: Gustav Fischer Verlag. $310 \mathrm{~S}$.

LEIBUUNDGUT, H. (1986): Ziele und Wege der naturnahen Waldwirtschaft. Schweiz. Zeitschr. f. Forstwesen, 137, 245-250.

LEIBBUNDGUT, H. (1993): Europäische Urwälder. Verlag Paul Haupt, Bern, Stuttgart.

LUČić, V. (1966): Prilog poznavanju klimatskih odnosa na Igmanu. Rad Šum.fak. i Inst za šum. u Sarajevu 10 (2), 51-80.

MEYER, P. (1999): Bestimmung der Waldentwicklungphasen und der Strukturdiversität in Naturwäldern . Allg. Forst-u.J.-Ztg., 170. Jg. (10-11), 203-211.

MEYER, P., und POGODA, P. (2001): Entwicklung der räumlichen Strukturdiversität in nordwestdeutschen Naturwäldern. Allg. Forst- u.J.-Ztg., 172. Jg. (12), 213-220. 
MEYER, P., TABAKU, V., und LUEPKE, v. B. (2003): Die Struktur albanischer Rotbuchen-Urwälder - Ableitungen für eine naturnahe Buchenwirtschaft. Forstw. Cbl. 122, 47-58.

MEYER, P., BARTSCH, N., WOLF, B. (2003): Methoden der Totholzerfassung im Wald. Forstarchiv 74, 263-274.

MÜLLER, J. (2005): Waldstrukturen als Steuergröße für Artengemeinschaften in kollinen bis submontanen Buchenwäldern. Dissertation, München.

PINTARIĆ, K. (1978): Urwald Perućica als natürliches Forschungslaboratorium. Allgemeine Forst- und Waldzeitung 33 (24), 702-707.

PINTARIĆ, K. (1991): Uzgajanje šuma, II dio, Tehnika obnove i njege sastojine. Šumarski fakultet Univerziteta u Sarajevu, $246 \mathrm{~S}$.

SHANNON, C. E. and WEAVER, W. (1976): Mathematische Grundlagen der Informationstheorie. München, Wien, Oldenburg.

STEINER, H., FRANK, G. (2013): Stand dynamics in the Virgin Forest "Neuwald". $5^{\text {th }}$ Symposium for Research in protected Areas, Mittersill, 739-742.

TABAKU, V. (1999): Struktur von Buchen-Urwäldern in Albanien im Vergleich mit deutschen Buchen-Naturwaldreservaten und Wirtschaftswäldern. Dissertation, Cuvillier Verlag Göttingen.

SEBASTIA, M.-T., CASALAS, P., VOJNIKOVIĆ, S., BOGUNIĆ, F., BEUS, V. (2005): Plant diversity and soil properties in pristine and managed stands from Bosnian mixed forests. Forestry, Oxford University Press, Oxford, 78(3), 297-303.

VIŠNJić, Ć, VOJNIKOVIĆ, S., IORAS, F., DAUTBAŠić, M., ABRUDAN, I. V., GUREAN, D., LOJO, A., TREŠTiĆ, T., BALLIAN, D., und BAJRIĆ, M. (2009): Virgin Status Assessment of Plješevica Forest in Bosnia- Herzegovina. Not. Bot. Agrobot. Cluj, 37(2), 22-27.

ViŠNJić, Ć., SOLAKOVIĆ, S., MEKIĆ, F., BALIĆ, B., VOJNIKOVIĆ, S., DAUTBAŠiĆ, M., GURDA, S., IORAS, F., RATNASINGAM, J., ABRUDAN, I. V., (2013): Comparison of structure, regeneration and dead wood in virgin forest remnant and managed forest on Grmeč Mountain in Western Bosnia. Plant biosystems 2013 v.147 no.4 pp. 913-922

VRŠKA, T., HORT, L., ODEHNALOVA, P., ADAM, D., HORAL, D. (2001): The Milešice virgin forest after 24 years $(1972$ - 1996). Journal of Forest Science 47(6), 255 276. 


\section{SAŽETAK}

U radu su prezentirani rezultati istraživanja strukturnog sastava, dinamike, teksture i diverziteta razvojnih faza prašume "Ravna vala" na Bjelašnici. Prašuma "Ravna vala" se nalazi u centralnom dijelu Bosne i Hercegovine, oko $20 \mathrm{~km}$ jugozapadno od Sarajeva na planini Bjelašnici, na nadmorskoj visini od 1280 do $1450 \mathrm{~m}$. Prvi put je opisana 1978. godine. Zbog svoje izuzetne vrijednosti i posebne dinamike rasta i razvoja često je bila predmetom istraživačkih projekata, što je i rezultiralo postavljanjem trajne eksperimentalne plohe kvadratnog oblika površine 1. ha. Istraživanja su provedena na trajnoj plohi u tri navrata: 1978, 1988 i 2008 godine, i na 46 privremenih sistematski postavljenih kružnih ploha radijusa 12,6 metara, od kojih svaka reprezentuje po 1 ha površine prašume.

U prašumi "Ravna vala" je utvrđeno prosječno 638 stabala po hektaru, pri čemu dominira bukva sa $77 \%$, dok jela učestvuje sa svega $18 \%$ u ukupnom broju stabala. U pogledu zalihe žive drvne mase u prašumi „Ravna vala” je utvrđeno prosječno $701 \mathrm{~m}^{3} /$ ha.

Analizom teksturnog diverziteta uočava se smjena pojedinih razvojnih faza prašume na malom prostoru, pri čemu su najzastupljenije optimalna faza $(28,7 \%)$, faza izjednačavanja $(24,9 \%)$ i faza podmlađivanja 22\%. Prosječni teksturni diverzitet prašume „Ravna vala“ pokazuje Shannonn-indeks od 1,69 dok je indeks izjednačenosti Evenness 0,86.

Analiza dinamike razvoja debljinske strukture po broju stabala pojedinih vrsta drveća je pokazala da se u vremenskom periodu od 30 godina broj stabala bukve u debljinskim klasama do $20 \mathrm{~cm}$ skoro utrostručio, dok je broj stabala jele u istim debljinskim klasama opao za polovinu.

U prašumi "Ravna vala" u toku je proces smjene glavnih vrsta drveća. Bukva u nižim debljinskim klasama zamjenjuje jelu i postepeno je potiskuje. Ovaj trend će se nastaviti i u budućnosti kada će bukva preuzeti glavnu ulogu i u većim debljinskim klasama. Smjena glavnih vrsta je pod uticajem prirodnih faktora a najveći značaj imaju klimatske promjene. Da je prašuma "Ravna vala" stabilna šumska zajednica pokazuje i njena tekstura i teksturni diverzitet. U prašumi je prisutno svih 7 razvojnih faza. Razvojne faze nisu grupisane već se javljaju na manjim površinama u čitavoj prašumi što dodatno povećava stabilnost prašume $\mathrm{i}$ omogućava ujednačeniji prelazak iz jedne faze u drugu bez izraženih turbulencija na većoj površini prašume. 